\title{
Evaluating Climate Change Mitigation and Adaptation Potential of Conservation Agriculture in Semi-arid Tropics of Southern India
}

\author{
Ram A. Jat ${ }^{1 *}$, Suhas P. Wani ${ }^{1}$, P. Pathak ${ }^{1}$, Piara Singh ${ }^{1}$, Kanwar L. Sahrawat ${ }^{1}$, \\ Girish Chander $^{1}$ and R. S. Sudi ${ }^{1}$
}

${ }^{1}$ International Crops Research Institute for the Semi-Arid Tropics (ICRISAT), Patancheru, 502324,

Telangana, India.

Authors' contributions

This work was carried out in collaboration between all authors. Authors SPW, PS and PP designed the study and wrote the protocol. Author RAJ conducted the study, generated and analyzed the data, and prepared the manuscript. Authors GC, RSS managed the soil and runoff analyses of the study. Author

$K L S$ managed the literature searches and reviewed the pre-submission draft. All authors read and approved the final manuscript.

Article Information

DOI: 10.9734/BJECC/2015/18479

Original Research Article

Received 24 $4^{\text {th }}$ April 2015 Accepted $10^{\text {th }}$ November 2015 Published 22 ${ }^{\text {nd }}$ December 2015

\begin{abstract}
Aims: As climate change related rainfall and temperature variability is being increasingly experienced in the SAT regions, we assessed climate change mitigation and adaptation potential of Conservation Agriculture (CA) by studying effects of minimum tillage (MT) and residue management practices on rain water use efficiency (RWUE), soil moisture, runoff, energy use and carbon dioxide emission in two maize-legume cropping systems.

Study Design: The experiment was laid out in split-split plot design with four replications.

Place and Duration of Study: The study was conducted at the International Crops Research Institute for the Semi-Arid Tropics (ICRISAT) farm, Patancheru, Telangana, India during 2010-11 and 2011-12.

Methodology: RWUE was calculated as maize equivalent yield divided by rainfall received during the crop season. Integrated digital runoff and soil loss monitoring unit (IDRSMU) was used to measure runoff. Soil moisture content was measured using the gravimetric method $(0-30 \mathrm{~cm}$ depth) and neutron probe (60-90 cm depth). The soil organic carbon was analyzed following the Walkley-Black method [1]. The diesel consumption in MT and conventional tillage (CT) was estimated following Downs and Hansen (http://www.ext.colostate.edu/pubs) and emission of $\mathrm{CO}_{2}$ was estimated according to EPA, 2009 [2].

Results: Tillage and residue management practices did not show significant effect on RWUE
\end{abstract}


except; CT having significantly higher RWUE over MT during 2011-12. Effect of cropping systems on RWUE was significant but variable during the two years of study. MT-RT (minimum tillageresidue retained) reduced total seasonal runoff by $28.62 \%$ and $80.22 \%$ compared to CT-RR (conventional tillage- residue removed) in 2010-11 and 2011-12, respectively. Similarly, MT-RT reduced rainwater loss and peak rate of runoff compared to CT-RR in both the years of study. During 2010, MT-RT had higher total soil moisture (v/v) in the 0-90 cm soil depth in sole as well as intercropped maize compared to CT-RR, however, during 2011 MT-RT had higher total soil moisture in sole maize only. As compared to CT, even though, MT improved SOC in 0-15 cm depth but lowered slightly in $15-30 \mathrm{~cm}$ depth. RT (residue retained) improved SOC in 0-15 and 15$30 \mathrm{~cm}$ depths compared to residue removal (RR). MT-RT had higher or equal SOC in 0-15 and 15$30 \mathrm{~cm}$ soil depths compared to CT-RR in both the maize-legume cropping systems. MT saved energy corresponding to 41.49 I of diesel per hectare annually compared to CT. Similarly, MT emitted $110.79 \mathrm{~kg}$ less $\mathrm{CO}_{2}$ annually on per hectare basis compared to CT due to reduced diesel use.

Conclusion: CA, when adopted by following good agricultural practices and refined to suit the local conditions, could emerge as sustainable production system for climate change mitigation and adaptation of dryland cropping systems in semi-arid tropics of southern India.

Keywords: Climate change; semi-arid tropics; conservation agriculture; minimum tillage; runoff; SOC; soil moisture.

\section{INTRODUCTION}

Climate change is now largely accepted as a real, pressing, and truly global problem [3]. There is strong likelihood of severe adverse effects of climate change on agricultural productivity and food security in much of the semi-arid tropics (SAT) [4]. Therefore, there is need to develop and disseminate alternate production technologies that provide a layer of resilience against climate change effects to ensure food and livelihood security for millions of smallholders in SAT. Achieving higher rain water use efficiency (RWUE) is vital for rainfed production systems to adapt to climate change related variabilities in rainfall. The improved growth of plants under Conservation Agriculture (CA) mainly due to higher and prolonged moisture availability [5-7], and improved soil quality [8] probably leads to higher RWUE. The CA enhances soil moisture content by improving infiltration of rain water $[9,10]$ and reducing evaporative loss of stored soil moisture [11]. The CA-led increase in soil organic matter improves water holding capacity of soil $[5,6,12,13]$. For example, an increase in organic matter in soil by one percent can increase water holding capacity by 25000 gallons of extra water in one acre [14]. It is predicted that due to climate change, most of the rain will occur in 'less frequent but more intense storms', leading to higher runoff loss [4]. Therefore, to maximize productive use of rain water, runoff loss of rain water needs to be minimized through in-situ and ex-situ water conservation measures. Surface retained residues in CA fields intercept the rainfall and provide a series of barriers for horizontally moving water, thus providing more time to infiltrate into the soil [12].

CA may help mitigate climate change by sequestering atmospheric carbon into the soil and reducing emission of greenhouse gases (GHGs) [15-18]. The results of several long-term studies have shown that continuous cropping results in loss of SOC as $\mathrm{CO}_{2}$ emission, but this can be reversed by implementing soil management practices under CA; e.g., no tillage with residue mulching will reduce loss of SOC via $C$ sequestration in the soil [19]. CA sequesters carbon due to continued accumulation of organic matter in the soil because of retention of crop residues and reduced rate of decomposition of crop residues [20]. Decreased fuel consumption in zero or reduced tillage, no residue burning, and reduced loss of nutrients especially $\mathrm{N}$ under $\mathrm{CA}$ practices lead to remarkable reduction in emission of GHGs [6,21]. Use of legume cover crops in CA reduces the need of nitrogen fertilizers, and also reduces nitrous oxide emissions [22]. Besides, deep-rooted leguminous crops can reduce nitrate leaching, thus further reducing the potential for denitrification from deeper layers [23]. The employing of diversified rotations in CA may also help increase methane absorption [24].

As climate change related rainfall and temperature variability is being increasingly experienced in the SAT regions [25], we attempted to evaluate the climate change mitigation and adaptation potential of CA by studying effects of minimumu tillage and residue 
management practices on RWUE, soil moisture, runoff, diesel use and carbon dioxide emissions in two maize-legume cropping systems during 2010-11 and 2011-12 seasons in an ongoing long-term experiment at the International Crops Research Institute for the Semi-Arid Tropics (ICRISAT) farm, Patancheru, Telangana, India.

\section{MATERIALS AND METHODS}

\subsection{Site Description}

A long-term experiment was initiated at the ICRISAT farm in Patancheru, India in 2009 rainy season to assess the potential of $\mathrm{CA}$ as an alternative production technology for sustainable crop intensification under rainfed situations in the SAT of southern India. The soil of experimental field was Vertic Inceptisol, which according to USDA is classified as a member of the fine, montmorillonite, isohyperthermic family of paralithic Vertic stopepts (Vertic cambisol as per FAO classification). The baseline information of experimental site is given in Table 1; and the layout of experimental field is given in Fig. 1 .

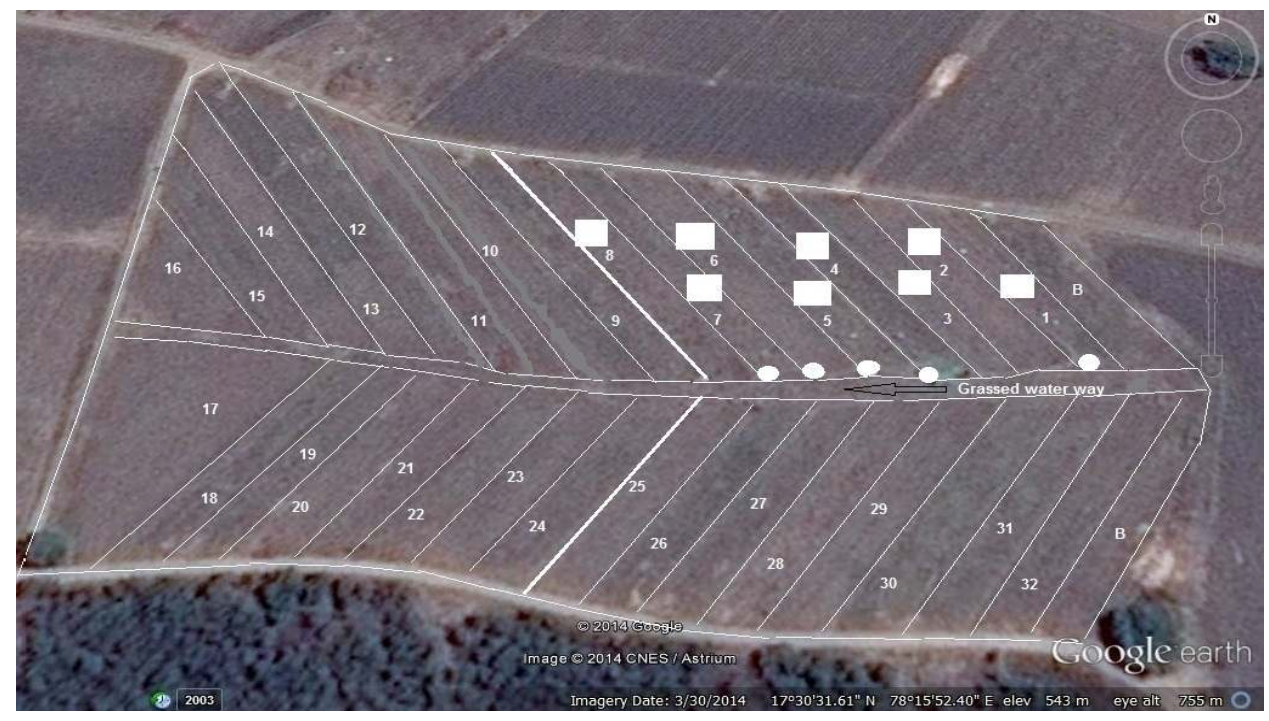

Fig. 1. Experimental field layout at ICRISAT research station

Numbers in the figure represent Plot Numbers. Filled rectangular boxes represent plots with soil moisture monitoring setups and filled circles represent plots with Integrated Digital Runoff and Soil Loss Monitoring Unit

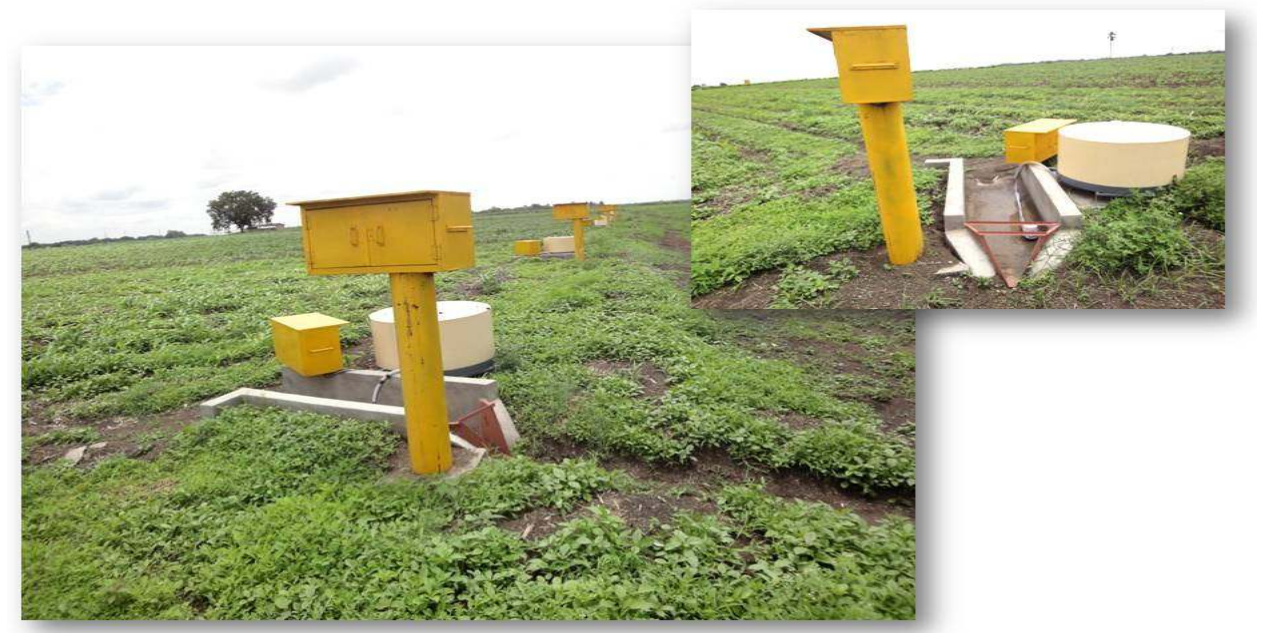

Fig. 2. A field view of the installed integrated digital runoff and soil loss monitoring unit (IDRSMU), photo in insert is close up of IDRSMU 
Table 1. Depth wise soil physical- chemical properties of the experimental site $(0-120 \mathrm{~cm})$

\begin{tabular}{|c|c|c|c|c|c|c|c|c|c|}
\hline $\begin{array}{l}\text { Depth } \\
\text { (m) }\end{array}$ & $\begin{array}{l}\text { Coarse sand } \\
(2.0-0.2)\end{array}$ & $\begin{array}{l}\text { Fine sand } \\
(0.2-0.02)\end{array}$ & $\begin{array}{l}\text { Silt } \\
(0.02-0.002)\end{array}$ & Clay $(<0.002)$ & $\mathrm{pH}$ & $\begin{array}{l}E C \\
d S / m\end{array}$ & $\begin{array}{l}\% \text { organic } \\
\text { C }\end{array}$ & $\begin{array}{l}\text { Total N } \\
\text { (kg/ha) }\end{array}$ & $\begin{array}{l}\text { Available P } \\
\text { (kg/ha) }\end{array}$ \\
\hline $0-15$ & 12.6 & 14.7 & 22.9 & 49.9 & 7.9 & 0.22 & 0.41 & 797.6 & 4.72 \\
\hline $15-30$ & 11.9 & 13.5 & 20.9 & 53.7 & 7.9 & 0.19 & 0.23 & 451.9 & 1.50 \\
\hline $30-60$ & 10.8 & 12.9 & 20.5 & 55.8 & 8.0 & 0.29 & 0.21 & 399.9 & 1.52 \\
\hline $60-90$ & 10.0 & 12.2 & 20.4 & 58.3 & 8.0 & 0.22 & 0.18 & 346.8 & 1.12 \\
\hline $90-120$ & 8.6 & 12.6 & 20.0 & 58.8 & 8.0 & 0.24 & 0.16 & 312.3 & 1.15 \\
\hline \multirow{2}{*}{$\begin{array}{l}\text { Depth } \\
\text { (m) }\end{array}$} & \multirow{2}{*}{$\begin{array}{l}\text { Exchangeable K } \\
\text { (kg/ha) }\end{array}$} & \multirow{2}{*}{$\begin{array}{l}\text { Available S } \\
\text { (kg/ha) }\end{array}$} & \multirow{2}{*}{$\begin{array}{l}\text { Available Fe } \\
\text { (ppm) }\end{array}$} & \multirow{2}{*}{$\begin{array}{l}\text { Available } \\
\text { Mn (ppm) }\end{array}$} & \multirow{2}{*}{$\begin{array}{l}\text { Available Cu } \\
\text { (ppm) }\end{array}$} & \multirow{2}{*}{$\begin{array}{l}\text { Available B } \\
\text { (ppm) }\end{array}$} & \multirow{2}{*}{$\begin{array}{l}\text { Available } \\
\text { Zn (ppm) }\end{array}$} & \multicolumn{2}{|c|}{ Water content $\left(\mathrm{g} \mathrm{g}^{-1}\right)$ at } \\
\hline & & & & & & & & $33 \mathrm{kPa}$ & $1500 \mathrm{kPa}$ \\
\hline $0-15$ & 172.0 & 8.60 & 9.57 & 21.20 & 1.62 & 0.44 & 0.62 & 0.34 & 0.26 \\
\hline $15-30$ & 211.5 & 5.87 & 7.60 & 13.47 & 1.47 & 0.30 & 0.35 & 0.37 & 0.28 \\
\hline $30-60$ & 218.5 & 6.17 & 7.22 & 13.85 & 1.47 & 0.40 & 0.31 & 0.40 & 0.30 \\
\hline $60-90$ & 232.5 & 6.15 & 7.07 & 12.15 & 1.52 & 0.46 & 0.27 & 0.43 & 0.32 \\
\hline $90-120$ & 230.0 & 8.07 & 6.75 & 11.82 & 1.50 & 0.52 & 0.26 & 0.43 & 0.32 \\
\hline
\end{tabular}




\subsection{Experimental Design, Treatments and Crop Management}

Two tillage treatments -- conventional tillage $(\mathrm{CT})$, minimum tillage (MT), and two residue management practices -- residue removed (RR) and residue retained (RT) -- and two cropping systems -- maize-chickpea sequence and maize/pigeonpea intercropping system with four replications, were tested in split-split plot design. The experiment was taken on permanent raised beds, the details on crop management practices followed are given in Table 2. Weeds were controlled by pre-emergence herbicide (pendimethalin $1.0 \mathrm{~kg}$ a.i. ha ${ }^{-1}$ ) application followed by manual (MT plots) and mechanical (CT plots) weeding. Post-emergence herbicides were not used due to non-availability of such herbicides for application in maize/pigeonpea intercropping systems. In both, sole maize in maize-chickpea sequence and maize / pigeonpea intercrops $100 \mathrm{~kg}$ di-ammonium phosphate (DAP) ha ${ }^{-1}$ was applied as basal dose followed by application of $100 \mathrm{~kg}$ urea ha ${ }^{-1}$ in two equal splits at 25 and 45 days after sowing during rainy season. In chickpea, $100 \mathrm{~kg}$ DAP ha

${ }^{1}$ was drilled at the time of sowing through seedcum-ferti drill. During 2010, before sowing of rainy season crops, soil test based application of iron, zinc, and boron was done. Insects were controlled by using recommended insecticides.

\subsection{Measurements}

RWUE was calculated as maize equivalent yield (calculated following [26]) divided by rainfall received during the crop season. Runoff data of rainy season from integrated digital runoff and soil loss monitoring unit (IDRSMU) [27], shown in Fig. 2, were analyzed to estimate runoff in different treatment plots in maize-chickpea system. Soil moisture content (60-90 cm depth) was measured during maize growing period using the neutron probe (Troxler model 4302) calibrated for the soil. Soil moisture in $0-30 \mathrm{~cm}$ soil depth was measured by gravimetric method. Post-harvest soil samples were collected during May, 2012 from 0 to $15 \mathrm{~cm}$ and 15 to $30 \mathrm{~cm}$ soil depths in each of the treatment plot across all four replications to determine SOC content. In each treatment plot, six sub-samples were collected, mixed thoroughly to get about $1 / 2 \mathrm{~kg}$ representative composite sample. Collected soil samples were air dried, ground and passed through $0.25 \mathrm{~mm}$ sieve. The SOC was analyzed following the Walkley-Black method [1]. The diesel consumption in MT and CT was estimated following Downs and Hansen (http://www.ext.colostate.edu/pubs) and emission of $\mathrm{CO}_{2}$ was estimated according to EPA [2].

\subsection{Statistical Analysis}

Data were statistically analyzed using GenStat Discovery Edition 3 as a split-split design with four replications. Main and interaction effects were compared using Fisher's protected LSD (least significant difference; $p<0.05$ ).

\section{RESULTS AND DISCUSSION}

\subsection{RWUE}

RWUE was found lower in 2010-11 than that in the 2011-12 (Table 3). During 2010-11, the total rainfall received was $1071 \mathrm{~mm}$ as against only $409 \mathrm{~mm}$ received during 2011-12. The extra rain received during 2010-11 did not improve crop yields remarkably over that in 2011-12, rather rain water was lost as runoff, leading to lower RWUE in 2010-11 than that in 2011-12. RWUE was $3.94 \%$ and $9.09 \%$ higher in CT compared to MT during 2010-11 and 2011-12, respectively but the difference was significant only during 201112 season (Table 3). The lower RWUE in MT could be attributed to lower plant stand (data not presented here) and lack of timely weeding in MT during 2011-12 season, leading to lower crop yields in MT. In MT, as weeding was done manually it took longer time; and was interrupted and delayed by frequent rainfall whereas in CT weeding was accomplished quickly with the help of tropicultor mounted hoe. RWUE was similar under RR and RT in 2010-11, but RWUE was higher by $5.30 \%$ under RR as compared to RT in 2011-12. The difficulty in sowing through surface retained residues and poor seed to soil contact led to lower plant stand and crop yield in RT. In northern Cameroon, the presence of mulch (of Brachiaria ruziziensis and Calopogonium mucunoides) negatively affected cotton seedling stand by 13-14\% compared to non-mulched plots [28]. Achieving acceptable plant stands in $\mathrm{CA}$ is a challenge, and highlights the need for suitable seeding machinery and understanding of the management aspects in the CA systems [29]. Besides, the retention of crop residues might have reduced the availability of plant nutrients temporarily [6]. Maize-chickpea system had $25.36 \%$ higher RWUE $(P<0.05)$ compared to maize/pigeonpea intercropping system in 201011 mainly due to lower yield of pigeonpea 
because of severe insect-pest attack (Table 3 ). While maize/pigeonpea intercropping system had 43.74\% higher RWUE $(P<0.05)$ as compared to maize-chickpea system during 2011-12, and this could be attributed to higher maize yield under maize/pigeonpea intercropping, and the failure of chickpea crop due to lack of sufficient soil moisture during the germination of the crop. This indicates that the maize/pigeonpea intercropping could provide better resilience against seasonal rainfall variabilities compared to maize-chickpea system in semi-arid tropical southern India.
RWUE was at par in MT-RT and CT-RR during 2010-11, but it was lower in MT-RT $(P<0.05)$ as compared to that in CT-RR during 2011-12 in both the cropping systems (Fig. 3). During 201112 in MT-RT incessant rainfall led to poor weed control possibly by making pre emergence herbicide application less effective, and manual weeding difficult, which led to lower yield in MTRT as compared to that in CT-RR. Whereas, weeds were controlled effectively and timely under CT-RR using a bullock drawn tropicultor mounted hoe.

Table 2. Management practices used in the maize- pigeonpea intercropping and maizechickpea sequence systems

\begin{tabular}{ll}
\hline Treatment & \multicolumn{1}{c}{ Management } \\
\cline { 2 - 3 } & $\begin{array}{l}\text { Maize- pigeonpea intercropping } \\
\text { system }\end{array}$ \\
\hline MT-RT: Minimum & Tillage was not done except reshaping of \\
tillage, residue & $\begin{array}{l}\text { beds and furrows after harvesting } \\
\text { retained }\end{array}$ \\
& two rows of maize, with one interrow of \\
pigeonpea, were sown on each \\
permanent raised bed (width; 1.0 meter) \\
with zero seed-cum-ferti drill during rainy \\
season; remaining biomass of maize after \\
harvest of cobs was spread out between \\
the rows of pigeonpea; after harvesting of \\
pods the pigeonpea stover was spread \\
out on the beds after chopping.
\end{tabular}
tillage, residue removed

CT-RT:

Conventional tillage, residues incorporated

MT-RR: Minimum
As in MT-RT except residues of both maize and pigeonpea were removed from the field.

Conventional tillage consisting of a series of operations including mouldboard ploughing, chisel ploughing, cultivation, blade harrowing followed by reshaping of beds and furrows was done after harvesting of pigeonpea during the summer season; sowing was done as in MT-RT; remaining biomass of maize after harvest of cobs was spread out between the rows of pigeonpea; after harvesting of pods the pigeonpea stover was spread out on the beds after chopping and incorporated into the soil during tillage.
Maize- chickpea sequence system

Tillage was not done except reshaping of beds and furrows after harvesting chickpea during the summer season; two rows of maize were sown on each permanent raised bed (width; 1.0 meter) with zero seedcum-ferti drill during rainy season;; four rows of chickpea were sown on each permanent raised bed with zero seed-cum-ferti drill without any tillage after harvest of maize; remaining biomass of maize after harvest of cobs was spread out between the rows of chickpea; chickpea residues were spread on beds after harvest.

As in MT-RT except residues of both maize and chickpea were removed from the field.

Conventional tillage consisting of a series of operations including mouldboard ploughing, chisel ploughing, cultivation, blade harrowing followed by reshaping of beds and furrows was done after harvesting of chickpea during the summer season; sowing of maize and chickpea was done as in MT-RT; remaining biomass of maize after harvest of cobs was spread out between the rows of chickpea; the chickpea residues were spread out on the beds and incorporated into the soil during tillage.

As in CT-RT except maize and pigeonpea residues were removed from the field. 
Jat et al.; BJECC, 5(4): 324-338, 2015; Article no.BJECC.2015.023

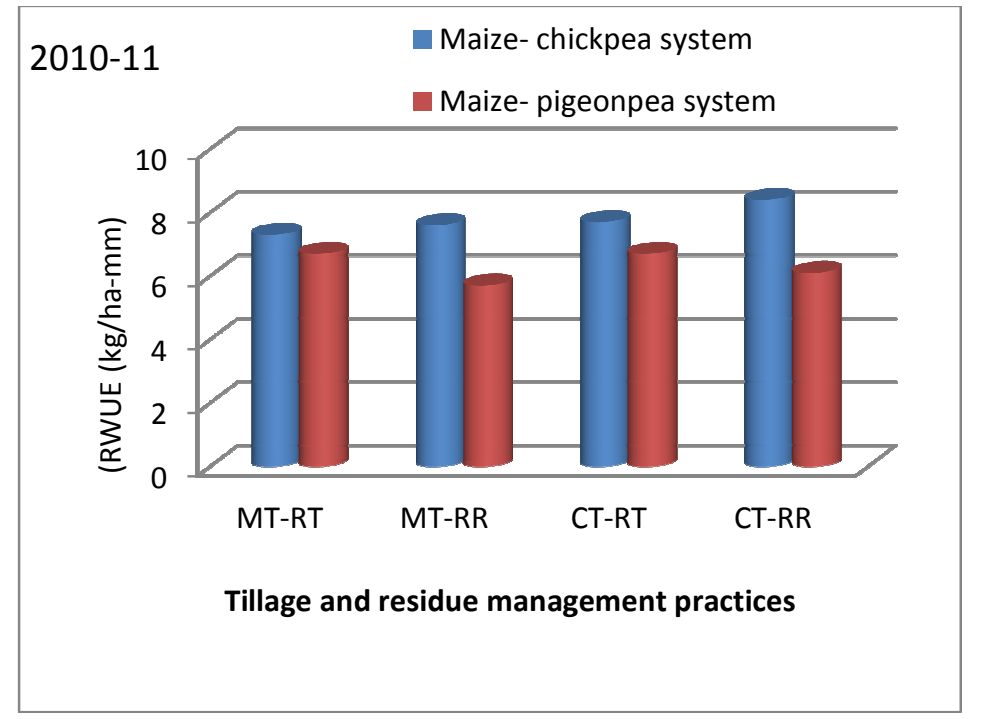

2011-12

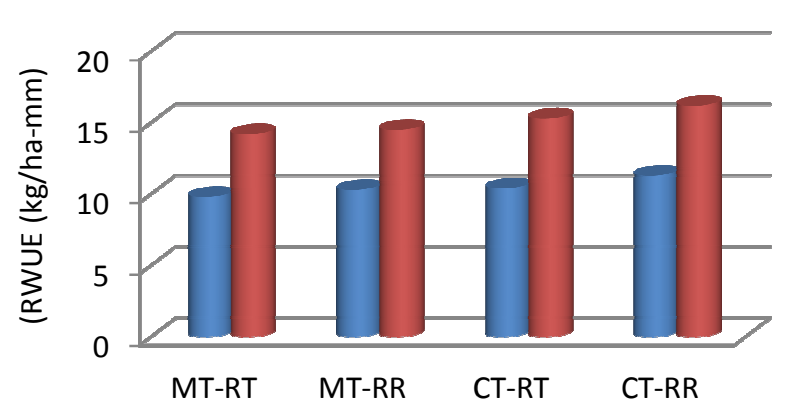

Tillage and residue management practices

Fig. 3. Effects of tillage and residue management practices on rain water use efficiency in maize-chickpea and maize/pigeonpea intercropping systems

Notes: $R W U E=$ Rain water use efficiency; $M T=$ Minimum tillage; $C T=$ Conventional tillage; $R R=$ Residue removed; $R T=R e s i d u e$ retained 
CA is well known to improve RWUE particularly in low rainfall areas but, for productive use of stored soil moisture, timely and effective weed control is essential as weeds compete more with crop plants for soil moisture than nutrients in drylands situations [30]. Besides, ensuring optimum plant stand under CA is also a must to obtain higher RWUE [29]. Retention of crop residues under $\mathrm{CA}$ although helps improve soil moisture content [5] but, at the same time, it can cause nutrient deficiency through immobilization [6,15]; therefore, efficient nutrient management also must be given due attention especially during the initial years of shifting to CA.

\subsection{Runoff and Peak Rate of Runoff}

MT-RT reduced total seasonal runoff by 28.6 and 80.22 compared to MT-RR during 2010 and 2011, respectively (Table 4). Only 17.5 and $1.3 \%$ of total rainwater was lost as runoff under MT-RT compared to 24.4 and $6.4 \%$ under MT-RR during 2010 and 2011, respectively. These results imply that under CA higher rainwater infiltrated into the soil to add to the green water. MT-RR had lesser runoff compared to CT-RR in both the years of study. Similarly, peak rate of runoff, which indicates erosive capacity of runoff water, decreased by 25.1 and $72.7 \%$ under MT-RT compared to CT-RR during 2010 and 2011, respectively (Table 4).

CA helps improve water infiltration and reduce runoff through improved soil cohesion, pore continuity, and aggregate stability, and the protection of the soil surface from the direct impact of rain drops [31]. There is a clear relationship between retention of mulch and reduction of runoff and soil loss by erosion $[32,33]$. Retention of crop residues on the surface in CA prevents surface sealing and provides a series of barriers to overland flow, thus, improving infiltration and reducing runoff. The placement of straw over the soil surface also reduces runoff velocity along the slope, thereby decreasing the erosivity of runoff water, besides trapping the sediments carried by overland flow [34].

\subsection{Soil Moisture (v/v)}

During 2010, MT-RT had 2.25 and 5.49\% higher total soil moisture $(\mathrm{v} / \mathrm{v})$ in the $0-90 \mathrm{~cm}$ soil depth in sole maize (in maize-chickpea sequence) and intercropped maize respectively, compared to CT-RR (Fig. 4). During 2011, MT-RT had 1.95\% higher total soil moisture $(\mathrm{v} / \mathrm{v})$ in $0-90 \mathrm{~cm}$ depth in sole maize, but in intercropped maize MT-RT had $1.31 \%$ less total soil moisture compared to CT-RR; even though MT-RT had higher soil moisture in surface layers but it had less soil moisture in deeper layers compared to CT-RR. In CA plots, most of the rainfall is harnessed as effective rainfall, with little runoff, leading to longer and reliable moisture regime for crop growth, and this improves drought proofing [10]. Residues intercept the rainfall and release it more slowly afterwards, which helps to maintain higher moisture level in soil, leading to extended water supply for plants [12]. Besides, the addition of organic matter in the form of crop residues improves water holding capacity of soils $[6,13]$ which is more true in the case of SAT soils, which are low in organic matter. Even a slightly higher soil moisture content in CA fields during the critical periods of plant growth may prove crucial to save plants or produce higher yield in the face of drought like situations in the dryland production systems.

\subsection{Soil Organic Carbon}

\subsubsection{0-15 cm depth}

Even though the differences in SOC content under different tillage and residue management practices were non-significant, CT caused slight decrease in SOC, while MT maintained SOC as compared to baseline SOC level. RR caused $9.75 \%$ decrease in SOC while RT improved SOC by $4.87 \%$ over baseline level (Table 3 ). In maizechickpea sequence, SOC decreased by $12.19 \%$; while in maize-pigeonpea intercropping system SOC increased by $7.31 \%$ compared to the baseline SOC level. MT improved SOC slightly over CT while RT improved SOC by $16.21 \%$ over RR. Maize/pigeonpea intercropping system had $22.22 \%$ higher $(P<0.05)$ SOC over the maizechickpea sequence which could be attributed to higher biomass addition through maize and pigeonpea residues.

MT-RT had higher SOC in $0-15 \mathrm{~cm}$ soil depth compared to CT-RR in both the maize-legume cropping systems (Fig. 5).

\section{$\underline{3.4 .215-30 \mathrm{~cm} \text { depth }}$}

In 15-30 cm soil depth, both CT and MT improved SOC by 13.04 and 8.69 percent, respectively over the baseline SOC level (Table 3). Similarly, both RT and RR enhanced SOC by 8.69 and 13.04 percent, respectively over baseline level. Both maize-chickpea sequence and maize-pigeonpea intercropping 
system increased SOC by $13.04 \%$ over baseline level. MT had slightly lesser SOC compared to $\mathrm{CT}$, while RT had slightly higher SOC over RR in $15-30 \mathrm{~cm}$ depth. No difference was found in SOC between two cropping systems. MT-RT had slightly higher or equal SOC in $15-30 \mathrm{~cm}$ soil depth compared to CT-RR in two maize-legume cropping systems (Fig. 5).

In MT, relatively higher SOC in $0-15$ soil depth and lower SOC in 15-30 cm soil depth could be attributed to lack of mechanical soil inversion under MT [35,36]. Calegari et al. [37] also reported higher SOC in surface layers in response to adoption of CA. CA leads to improvement in SOC due to reduced decomposition of soil organic matter and retention of biomass as mulch [15,20]. Crop rotation also have an impact on soil carbon by means of addition of foliage and root mass returned to the soil [22]. Reduced soil disturbance may also lead to higher carbon sequestration in CA fields due to slower decomposition of biomass added and oxidation of SOM [19]. Besides, greater micro-aggregation and aggregate stability due to CA [8] may lead to higher carbon sequestration in the CA fields.

\subsection{Energy Use}

In MT, tillage operations such as moldboard plowing, chisel plowing, cultivation, and blade harrowing, and mechanical interculturing were omitted. This saved energy corresponding to 41.49 I of diesel per hectare annually (Fig. 6). Mousques and Friedrich [5] reported an average saving of $15.5 \mathrm{~kg}$ fuel ha ${ }^{-1}$ by following the CA system in DPRK (Democratic People Republic of Korea). Fernandes et al. [38] from a study conducted in Brazil, estimated a diesel saving of $6.4 \mathrm{I} \mathrm{ha}^{-1}$ by tractors when CT was replaced by MT; and the total energy budget was lower by 25.5 I diesel equivalent $\mathrm{ha}^{-1}$. Duiker and Thomason [22] stated in a review that 'reduced use of machinery and elimination of tillage in CA reduces fossil fuel needs and hence $\mathrm{CO}_{2}$ emissions compared with CT systems [39] and improves energy efficiency of crop production [40]'. Integration of leguminous cover crops in CA reduces the need for nitrogenous fertilizers, which represents up to $30 \%$ of fossil fuel consumption in crop production [41].

\section{6 $\mathrm{CO}_{2}$ Emission}

As MT saved 41.49 I of diesel per hectare, it emitted $110.79 \mathrm{~kg}$ less $\mathrm{CO}_{2}$ annually on a per hectare basis compared to CT (Fig. 6). Burning of one litre of diesel emits $2.67 \mathrm{~kg} \mathrm{CO} 2$ [2]. Besides, with gradual improvement in soil health and fertility under CA, fertilizer requirement is expected to come down in the medium to longterm which would help to reduce emission of green house gases (GHGs) during fertilizer manufacturing and their post-field application.

Table 3. Effects of tillage, crop residue management practices and cropping systems on rain water use efficiency and soil organic carbon

\begin{tabular}{lllll}
\hline \multirow{2}{*}{ Treatment } & \multicolumn{2}{c}{ RWUE (kg/ha-mm) } & \multicolumn{2}{c}{ SOC (\%) } \\
\cline { 2 - 5 } & \multicolumn{2}{c}{ Years } & \multicolumn{2}{c}{ Soil depth } \\
\cline { 2 - 5 } & $\mathbf{2 0 1 0 - 1 1}$ & $\mathbf{2 0 1 1 - 1 2}$ & $\mathbf{0 - 1 5} \mathbf{~ c m}$ & $\mathbf{1 5 - 3 0 ~} \mathbf{~ m}$ \\
\hline Tillage practices & & & & \\
Conventional tillage (CT) & 7.11 & 13.32 & 0.40 & 0.26 \\
Minimum tillage (MT) & 6.84 & 12.21 & 0.41 & 0.25 \\
SEd & 0.56 & 0.17 & 0.01 & 0.02 \\
$(P<0.05)$ & $\mathrm{NS}$ & 0.55 & $\mathrm{NS}$ & $\mathrm{NS}$ \\
Residue management & & & & \\
Crop residues removed (RR) & 6.97 & 13.09 & 0.37 & 0.25 \\
Crop residues retained (RT) & 6.98 & 12.43 & 0.43 & 0.26 \\
SEd & 0.29 & 0.36 & 0.03 & 0.01 \\
(P<0.05) & $\mathrm{NS}$ & $\mathrm{NS}$ & $\mathrm{NS}$ & $\mathrm{NS}$ \\
Cropping systems & & & & \\
Maize-Chickpea system & 7.76 & 10.47 & 0.36 & 0.26 \\
Maize/pigeonpea system & 6.19 & 15.05 & 0.44 & 0.26 \\
SEd & 0.33 & 0.38 & 0.02 & 0.01 \\
$(P<0.05)$ & 0.73 & 0.83 & 0.06 & $\mathrm{NS}$ \\
\hline
\end{tabular}

Note: RWUE= Rain water use efficiency; $S O C=$ Soil organic carbon. Baseline SOC level 0.41 percent $(0-15 \mathrm{~cm})$ and 0.23 percent $(15-30 \mathrm{~cm})$ 
Jat et al.; BJECC, 5(4): 324-338, 2015; Article no.BJECC.2015.023
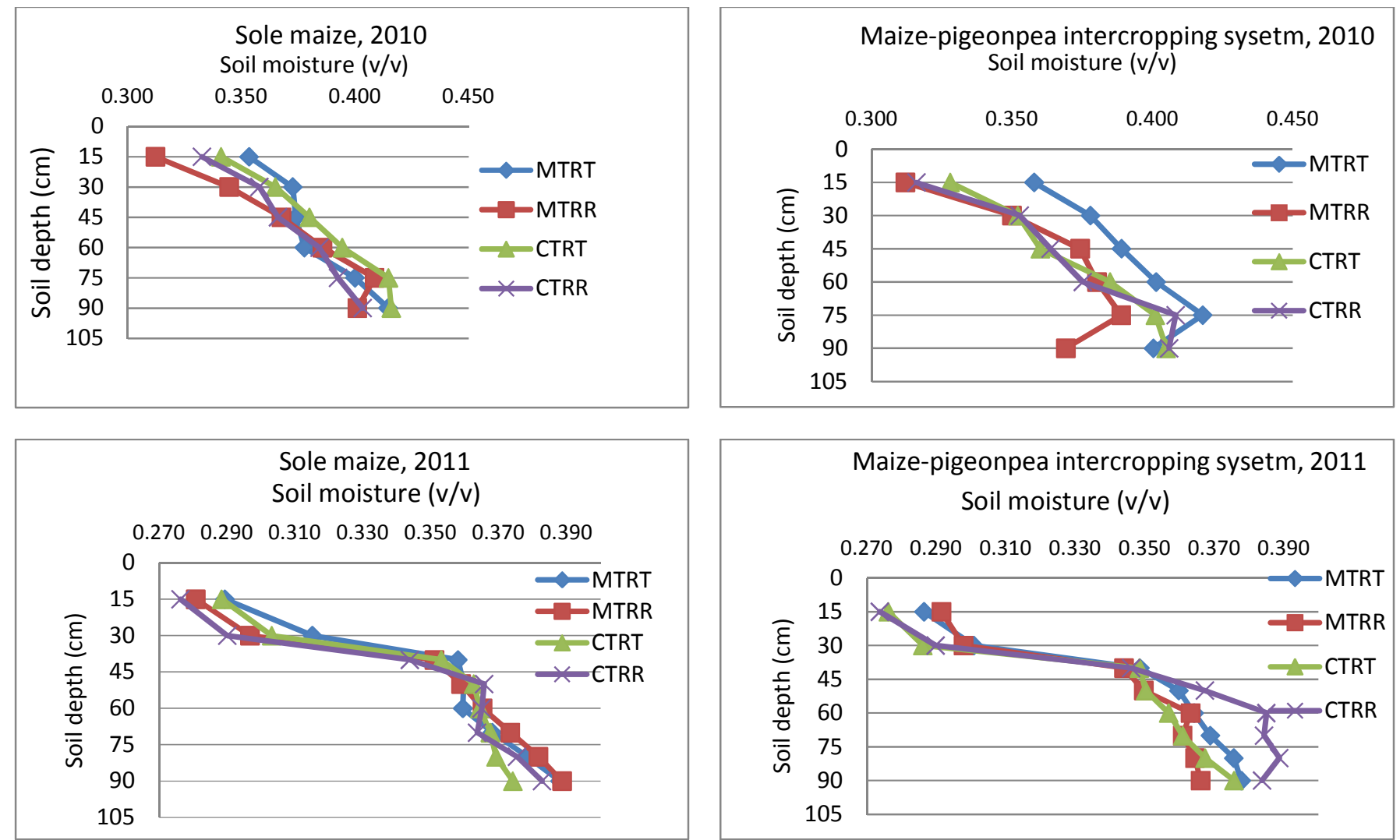

Fig. 4. Effects of tillage and residue management practices on soil moisture content in sole maize and maize/pigeonpea intercropping systems Notes: $M T=$ Minimum tillage; $C T=$ Conventional tillage; $R R=$ Residue removed; $R T=$ Residue retained 

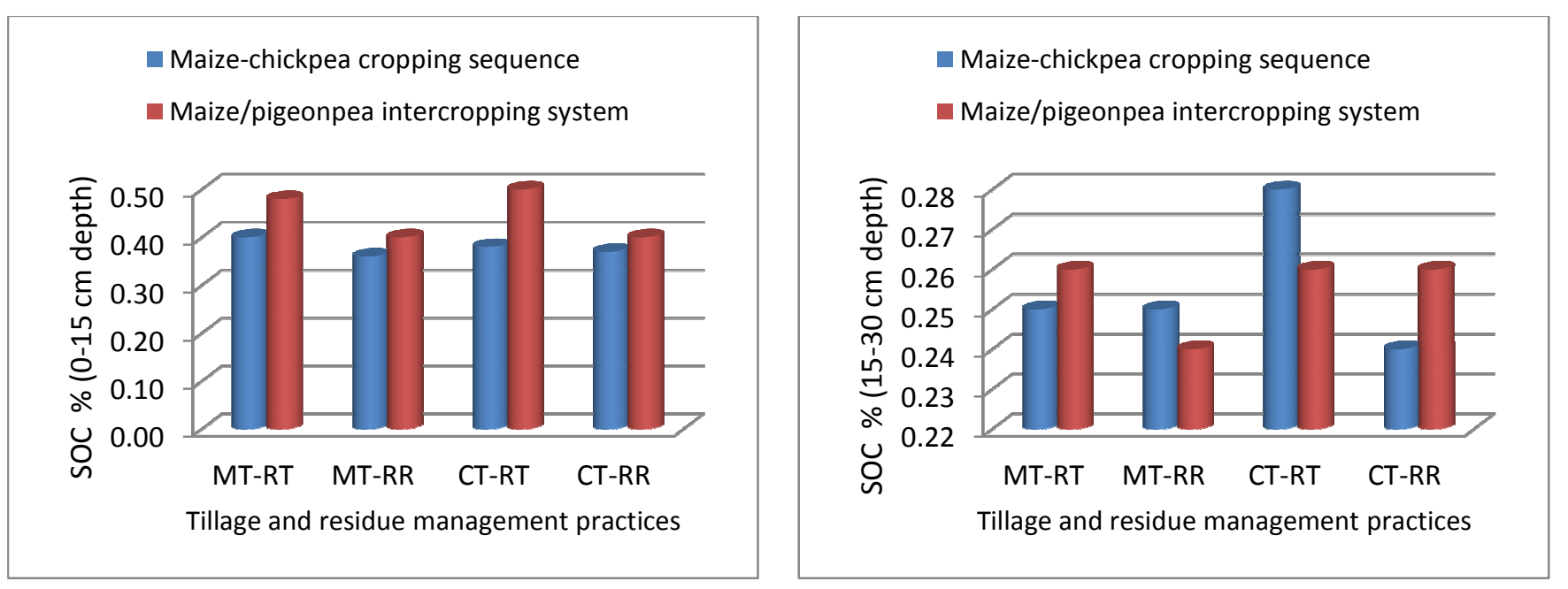

Fig. 5. Effects of tillage and residue management practices on soil organic carbon in maize-chickpea sequence and maize/ pigeonpea intercropping systems

Note: $M T=$ Minimum tillage; $C T=$ Conventional tillage; $R R=$ Residue removed; $R T=$ Residue retained 
Jat et al.; BJECC, 5(4): 324-338, 2015; Article no.BJECC.2015.023
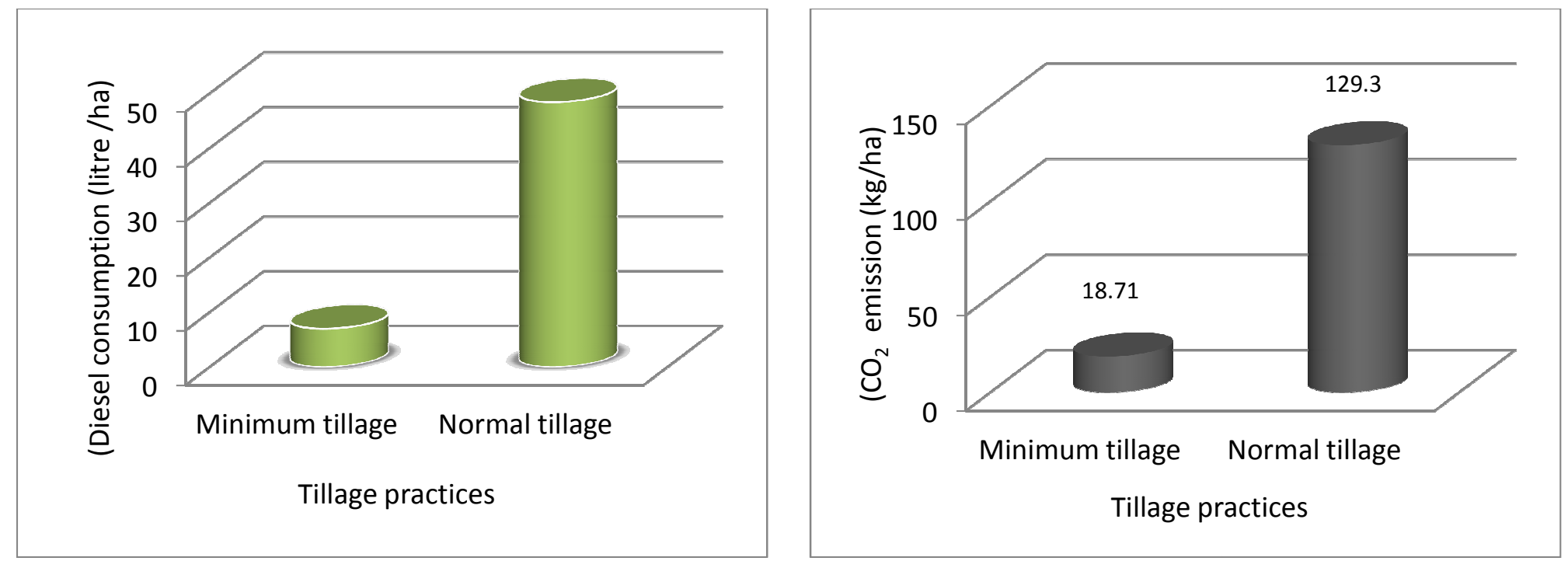

Fig. 6. Effects of tillage and residue management practices on diesel consumption and $\mathrm{CO}_{2}$ emission from diesel burning Note: $M T=$ minimum tillage; $C T=$ conventional tillage; $R R=$ residue removed; $R T=$ residue retained 
Table 4. Effects of tillage and crop residue management practices on runoff, peak rate of runoff and percent rainfall lost as runoff

\begin{tabular}{|c|c|c|c|c|c|c|}
\hline \multirow[t]{2}{*}{ Treatments } & \multicolumn{3}{|c|}{2010} & \multicolumn{3}{|c|}{2011} \\
\hline & $\begin{array}{l}\text { Runoff } \\
\text { (mm) }\end{array}$ & $\begin{array}{l}\text { Peak rate of } \\
\text { runoff } \\
\text { (cum/s/ha) }\end{array}$ & $\begin{array}{l}\text { Percent } \\
\text { rainfall lost } \\
\text { as runoff }\end{array}$ & $\begin{array}{l}\text { Runoff } \\
\text { (mm) }\end{array}$ & $\begin{array}{l}\text { Peak rate of } \\
\text { runoff } \\
\text { (cum/s/ha) }\end{array}$ & $\begin{array}{l}\text { Percent } \\
\text { rainfall } \\
\text { lost as } \\
\text { runoff }\end{array}$ \\
\hline $\begin{array}{l}\text { Conventional } \\
\text { tillage -residue } \\
\text { removed }\end{array}$ & 262.1 & 0.183 & 24.4 & 26.3 & 0.011 & 6.4 \\
\hline $\begin{array}{l}\text { Conventional } \\
\text { tillage -residue } \\
\text { retained }\end{array}$ & 202.0 & 0.130 & 18.8 & 7.2 & 0.004 & 1.8 \\
\hline $\begin{array}{l}\text { Minimum tillage - } \\
\text { residue removed }\end{array}$ & 253.4 & 0.126 & 20.0 & 11.8 & 0.005 & 2.9 \\
\hline $\begin{array}{l}\text { Minimum tillage - } \\
\text { residue retained }\end{array}$ & 187.1 & 0.137 & 17.5 & 5.2 & 0.003 & 1.3 \\
\hline
\end{tabular}

\section{CONCLUSION}

The results presented above indicate that in the absence of timely and effective weed control, and a less than optimum plant stand CA could not increase RWUE to maximize productive use of rain water. Therefore, to promote CA in SAT effective and economical control of weeds is important. Besides, for sowing through surface retained residues, the availability of customized machinery for smallholders is pre-requisite so as to ensure required plant stand. CA, by and large, increased soil moisture content, probably by increasing infiltration and water holding capacity of the soil, but again, to prevent wasteful loss of stored soil moisture effective and timely weed control is a must. Reduction in runoff and peak runoff rate was one of the most tangible benefits of CA. CA sequestered more carbon as compared to conventional practice particularly in the surface soil layers. CA also reduced emission of $\mathrm{CO}_{2}$ by lesser diesel use, but in the long-term the GHGs emission could be decreased further due to decreased demand for external plant nutrients and other inputs due to improved soil quality and greater resilience of production systems. As maize-pigeonpea intercropping system had significantly higher RWUE during low rainfall year (2011-12) and sequestered more SOC in $0-15 \mathrm{~cm}$ depth, it could be better suitable for climate change mitigation and adaptation in SAT compared to maize-chickpea sequence.

Thus, CA could emerge as sustainable production system for climate change mitigation and adaptation of dryland cropping systems in SAT of southern India, however, there is need to confirm above results through long term studies across different soil types and cropping systems.

\section{ETHICAL APPROVAL}

It is not applicable.

\section{ACKNOWLEDGEMENT}

This paper is based on the data generated from a long-term experiment conducted at ICRISAT, Patancheru. Authors acknowledge the help and contribution of all the scientists and staff who have been associated with this experiment.

\section{COMPETING INTERESTS}

Authors have declared that no competing interests exist.

\section{REFERENCES}

1. Nelson DW, Sommers LE. Total carbon, organic carbon, and organic matter. In: Sparks DL, et al. editors. Methods of soil analysis. Part 3. Chemical Methods. SSSA Book Series No. 5, SSSA and ASA, Madison, WI. 1996;961-1010.

2. EPA. Emission facts: Average carbon dioxide emissions resulting from gasoline and diesel fuel. US Environmental Protection Agency; 2009. Accessed 25 May 2009.

Available:http://www.epa.gov/oms/climate/ basicinfo.htm

3. FAO. Climate change, water and food security. 2014; accessed on 18 July, 2014).

Available:http://www.fao.org/docrep/014/i2 096e/i2096e01.pdf

4. IPCC. The Physical Science Basis, Contribution of Working Group I to the 
Fourth Assessment Report of the Intergovernmental Panel on Climate Change, Cambridge University Press, Cambridge, UK. 2007;1009.

5. Mousques $\mathrm{C}$, Friedrich $\mathrm{T}$. Conservation Agriculture in China and the Democratic People's Republic of Korea. FAO crop and grassland service working paper. Rome: Food and Agriculture Organization of the United Nations; 2007.

6. Nurbekov A. Manual on conservation agriculture practices in Uzbekistan. Tashkent, Uzbekistan. 2008;40.

7. Jat RA, Sahrawat KL, Kassam A, Friedrich $\mathrm{T}$. Conservation agriculture for sustainable and resilient agriculture: Global status, prospects and challenges. In: Jat RA, Sahrawat KL, Kassam A, editors. Conservation Agriculture: Global Prospects and Challenges, CAB International, UK. 2014;1-25.

8. Verhulst N, Govaerts B, Verachter, E, Castellanos-Navarrete A, Mezzalama M, Wall PC, Chocobar A, Deckers J, Sayre KD. Conservation agriculture, improving soil quality for sustainable production systems? In: Lal R, Stewart BA, editors. Food security and Soil quality. Boca Raton, Florida: CRC Press. 2010;137-208.

9. Govaerts B, Fuentes M, Mezzalama M, Nicol JM, Deckers J, Etchevers JD, Figueroa- Sandoval B, Sayre KD. Infiltration, soil moisture, root rot and nematode populations after 12 years of different tillage, residue and crop rotation managements. Soil Till. Res. 2007;94: 209-219.

10. Shaxson $F$, Kassam A, Friedrich $T$, Boddey B, Adekunle A. Underpinning Conservation Agriculture's Benefits: The Roots of Soil Health and Function. Background document for the: Workshop on Investing in Sustainable Crop Intensification: The Case for Improving Soil Health, Italy, Plant Production and Protection Division (AGP). Rome: Food and Agriculture Organization of the United Nations; 2008.

11. Scopel E, Da Silva FAM, Corbeels M, Affholder FO, Maraux F. Modelling crop residue mulching effects on water use and production of maize under semi-arid and humid tropical conditions. Agronomie. 2004;24:383-395.

12. Scopel E, Findeling A. Conservation tillage effects on runoff reduction in rainfed maize of semi-arid zones of western Mexico. In:
Garcia-Torres L, Benites J, Martinez-Vilela A, editors. In: Proc. $1^{\text {st }}$ world congress on conservation agriculture "conservation agriculture- a worldwide challenge". Madrid, October 1-5. XUL, Cordoba, Spain. 2001;179e184.

13. Govaerts B, Sayre KD, Goudeseune B, De Corte P, Lichter K, Dendooven L, Deckers J. Conservation agriculture as a sustainable option for the central Mexican highlands. Soil Till. Res. 2009;103: 222-230.

14. Akin TA. "Don't treat soil like dirt!" or "Is your soil healthy? 2014. Accessed 12 August, 2014.

Available:http://www.ecolandscaping.org/0 7/soil/dont-treat-soil-like-dirt-or-is-your-soilhealthy/

15. Giller KE, Witter E, Corbeels M, Tittonell P. Conservation agriculture and smallholder farming in Africa: The heretics' view. Soil Till. Res. 2009;114:23-34.

16. Hobbs PR, Govaerts B. How conservation agriculture can contribute to buffering climate change. In: Reynolds MP, editor. Climate Change and Crop Production, CAB International. 2010;177-199.

17. Kassam A, Friedrich T, Shaxson F, Pretty $J$. The spread of conservation agriculture: Justification, sustainability and uptake. International J. Agric. Sustainability. 2009; 7(4):1-29.

18. Kassam A, Friedrich $T$, Shaxson $F$, Reeves T, Pretty J, Moraes Sá JC de. Production systems for sustainable intensification integrating productivity with ecosystem services. Technikfolgenabschätzung- Theorie und Praxis 20. Jg., Heft 2. $2011 ; 38-45$.

19. Jat RA, Wani SP, Sahrawat KL. Conservation agriculture in the semi-arid tropics: Prospects and problems. In: Sparks DL, editor. Adv. Agronomy. 2012b; 117:191-273.

20. Corbeels M, Scopel E, Cardoso A, Bernoux M, Douzet JM, Neto MS. Soil carbon storage potential of direct seeding mulch-based cropping systems in the Cerrados of Brazil. Global Change Biol. 2006;12:1773-1787.

21. Corsi S, Friedrich T, Kassam A, Pisante M, Sà $J$ de $M$. Soil organic carbon accumulation and greenhouse gas emission reductions from Conservation Agriculture: A literature review. Integrated Crop Management. FAO, Rome. 2012;16. 
22. Duiker SW, Thomason W. Conservation Agriculture in the USA, In: Jat RA, Sahrawat KL, Kassam A, editors. Conservation Agriculture: Global Prospects and Challenges, CAB International, UK. 2014;26-53.

23. Meisinger JJ, Delgado JA. Principles for managing nitrogen leaching. J. Soil and Water Conservation. 2002;57:485-498.

24. Sainju UM, Stevens WB, Caesar-Tonthat $\mathrm{T}$, Liebig MA. Soil greenhouse gas emissions affected by irrigation, tillage, crop rotation, and nitrogen fertilization. J. Environmental Quality. 2012;41: 1774-1786.

25. Jat RA, Craufurd $P$, Sahrawat KL, Wani SP. Climate change and resilient dryland systems: Experiences of ICRISAT in Asia and Africa. Current Science. 2012a; 102(12):1650-59.

26. Verma SP, Modgal SC. Use of equivalent yields in cropping systems. Himachal J. Agric. Res. 1983;9(2):89-92.

27. Pathak P, Chandrashekar K, Sudi R, Wani SP. Technical descriptions and operating manual- integrated digital runoff and soil loss monitoring unit. International Crops Research Institute for the Semi-Arid Tropics (ICRISAT), Patancheru, India. 2011;1-20.

28. Brévault $T$, Guibert $H$, Naudin $K$. Preliminary studies of pest constraints to cotton seedlings in a direct seeding mulchbased system in Cameroon. Experimental Agriculture. 2009;45:25-33.

29. Wall PC, Thierfelder C, Ngwira A, Govaerts B, Nyagumbo I, Baudron F. Conservation Agriculture in Eastern and Southern Africa. In: Jat RA, Sahrawat KL, Kassam A, editors. Conservation Agriculture: Global Prospects and Challenges, CAB International, UK. 2014; 263-292.

30. Croissant RL, Peterson GA, Westfall DG. Dryland cropping systems. Fact sheet No. 0.516. Colorado State University, Division of Extension; 2014. Accessed 07 June, 2014.

Available:http://www.ext.colostate.edu/pub s/crops/00516.html

31. Basch G, Kassam A, Friedrich $T$, Santos FL, Gubiani PI, Calegari A, Reichert JM, Dos Santos DR. Sustainable soil water management systems. In: Lal R, Stewart
BA editors. Soil Water and Agronomic Productivity Advances in Soil Science. CRC Press, Boca Raton, Florida. 2012; 229-288.

32. Lal R, Kimble JM, Follet RF, Cole CV. The Potential of U.S. Cropland to sequester carbon and mitigate the greenhouse effect. Chelsea, MI, USA: Sleeping Bear Press Inc.; 1998.

33. Erenstein $O$. Crop residue mulching in tropical and semi-tropical countries: An evaluation of residue availability and other technological implications. Soil Till. Res. 2002;67:115-133.

34. Danga BO, Wakindiki IIC. Effect of placement of straw mulch on soil conservation, nutrient accumulation, and wheat yield in a humid Kenyan highland. J. Tropical Agriculture. 2009;47(1-2):30-36.

35. Franzluebbers AJ. Water infiltration and soil structure related to organic matter and its stratification with depth. Soil Till. Res. 2002;66:197-205.

36. Kay BD, VandenBygaart. Conservation tillage and depth stratification of porosity and soil organic matter. Soil Till. Res. 2002;66:107-118.

37. Calegari A, Hargrove WL, Rheinheimer DDS, Ralisch R, Tessier D, Tourdonnet S, Guimarães M de F. Impact of long-term no-tillage and cropping system management on soil organic carbon in an Oxisol: A model for sustainability. Agron. J. 2008;100(4):1013-1019.

38. Fernandes HC, Silveira JCM, Rinaldi PCN. Avaliação do custo energético de diferentes operações agrícolas mecanizadas. Ciência e Agrotecnologia. 2008;32(5):1582-1587. Aaccessed 15 January 2013.

Available:http://www. scielo.br/scielo.php?

39. Uri ND. Conservation tillage and the use of energy and other inputs in US agriculture. Energy Economics. 1998;20:389-410.

40. Gelfand I, Snapp SS, Robertson GP. Energy efficiency of conventional, organic, and alternative cropping systems for food and fuel at a site in the US Midwest. Environmental Science and Technology. 2010;44:4006-4011.

41. Pimentel D. Energy inputs in food crop production in developing and developed nations. Energies. 2009;2:1-24.

(C) 2015 Jat et al.; This is an Open Access article distributed under the terms of the Creative Commons Attribution License (http://creativecommons.org/licenses/by/4.0), which permits unrestricted use, distribution, and reproduction in any medium, provided the original work is properly cited. 